\section{Sistema de Posicionamento \\ Global (GPS) e o Turismo}

Transports. The study also considers that in a short term the GPS will be very popular becoming an obligatory acessory for any traveller around the world.

KEYWORDS: Global Positioning System; GPS; tourism applications; attractions divulgation; touristisorientation.

\section{Sérgio M. Paz \\ Waldir Ferreira ${ }^{2}$}

Carlos E. Cugnasca ${ }^{3}$

RESUMO: Enfoca o Sistema de Posicionamento Global (GPS) e suas aplicações em Turismo. Apresenta considerações gerais sobre o sistema e destaca dez casos de sua aplicação em atividadesligadas aoturismo: nailha de Creta, nas praias do Brasil, no Atlântico e nos dois Pólos, na Costa Brasileira, em pontos culminantes dos continentes, nos Andes, nas estradas do Brasil, nas Américas, na Disney e nos transportes em geral. Considera que o GPS ser bastante popular, tornando-se um acessório obrigatório para qualquer viajante.

PALAVRAS-CHAVE: Sistema de posicionamento global; GPS; aplicações em turismo; divulgação de atrativos: orientação aos turistas.

ABSTRACT: Thisstudyemphasizes the Global PositioningSystem (GPS) and its applications in tourism. It presents general considerations about the system and point out ten cases of its applications in tourism as the following: Crete Isle; Brazilian Beaches; North and South Poles; Brazilian Coastland; Mountains; The Andes; The Americas; Brazilian Roads; American Mountains; Disneyworld; General

1. Bacharel em Engenharia Elétrica, emCiências da Computação eem Turismo pela Universidade de São Paulo (USP) Licenciado em Educação Física pela USP. Mestre e Doutorando em Engenharia Elétrica no Depto. de Engenhari da Computação e Sistemas Digitais da Escola Politéenica (POLI) da USP. Pesquisador do Laboratório de Automação Agrícola da POLI-USP

E-mail: smpaz@laa.pcs.usp.br

2. Bacharel em Relaçōes Públicas pela Escola de Comunicaçōes e Artes (ECA) da USP. Mestre e Doutor em Ciências da Comunicaçāo pela ECA/USP. Professor Assistente Doutor da ECA/US

3. Bacharel em Engenharia Elétrica pela POLI-USP. Mestre e Doutor em Engenharia Elétrica no Depto. de Engenharia da Computaçāo e Sistemas Digitais da POLl-USP. Coordenador do Laboratório de Automaçāo Agrícola
Professor Assistente Doutor da ECA/USP.

\section{Ciência da Navegaçāo}

\section{Navegação na Pré-História}

Tão antiga quanto a presença do ser humano na Terra é a noção de espaço, de posição. Movido pelo instinto de sobrevivência, o homem primitivo descobre que há espaço onde ele pode se resguardar das intempéries do clima - uma caverna, por exemplo(Paz, 1997). Esseespaço, porém, nãoé omaisadequado para obter alimentos. Ainda movido pelo instinto de sobrevivência, o "homem das cavernas" sai em busca de comida, vagando por espaços desconhecidos... até que encontra uma árvore carregada de frutas ou um lago cheio de peixes.

Saciado em seu apetite, novamente ele precisa de um abrigo. Ele poderia, portanto, sair vagando em busca de outra caverna. Mas o homem é um ser social. Há outros companheiros com os quais convive; alguns deles não saíram em busca de alimentos, e esperam que ele lhesleveuma fruta ou um peixe paracomer. Além disso, se aquela caverna em que estava lhe servia para suas necessidades, por que correr o risco de não encontrar outra antes que a chuva ou o frio voltem?

Nosso personagem precisa retornar à sua caverna. Felizmente, além de instintos, ele tem memória e inteligência. Durante o caminho de ida, ele notou peculiaridades: uma árvore mais alta, um tronco mais retorcido, uma pedra mais azulada, uma distante montanha à direita... Esses pontos lhe servem, agora, de referência, e o conduzem de volta.

Mais tarde, ele sentirá fome novamente. Outras vezes, ele sairá de sua caverna em busca de frutas ou peixes. Algumas vezes, ele voltará àquela mesma árvore frutífera, ou àquele mesmo lago, seguindo as mesmas referências: a árvore alta, o tronco retorcido, a pedra azul, a montanha. Em outras vezes, ele procurará novas frutas e novos peixes, e descobrirá novos caminhos, com novas referências.

Um dia, um raio derruba a árvore alta... Outrodia, ele encontra um outro tronco retorcido, muito parecido com o primeiro... Outro dia, ele erra a sua estimativa da distância à montanha... Outro dia, com tantos caminhos já aprendidos, sua memória falha, e ele se esquece do caminho original.

Nosso amigo tem problemas!

Mas ele tem, também, a inteligência para resolvê-los! Ele pensa: 
Árvores altas, às vezes caem. Troncos retorcidos, se parecem. É dificil avaliar a distância correta amontanhas distantes. Jáaquela pedra azulestá sempre ali, no mesmo lugar, facilmente identificável. Talvez eu deva procurar outras pedras que me orientem melhor... ou, se não as encontrar, eu mesmo irei colocá-las em meu caminho, de outras formas e cores, no lugar. da árvore, ou do tronco, ou na direção da montanha.. onde eu quiser! Para não me confundir, farei um desenho, no qual incluirei as principais referências que me levam às árvores com frutas e aos lagos compeixes. Esse desenho não só será útil a mim, mas também a meus companheiros, quando eu não puder mais fazer esse caminho!

Essa história tão simples vem se repetindo há milhares de anos. Muitas pedras azuis foram encontradas e outras tantas colocadas, marcando caminhos a serem seguidos, de modocada vez mais preciso e confiável. Muitos desenhos foram feitos, descrevendo esses caminhos, facilitando para os que os trilharam depois de seu descobridor. Às portas do terceiro milênio, essas pedras e esses desenhos estão tão sofisticados quanto precisos.

\section{Evolução da Navegação}

Como nosso amigo das cavernas, caminhando passo a passo, aos poucos foi ocorrendo o desenvolvimento dessa ciência chamada navegação.

$\mathrm{Na}$ medida em que iam sendo descobertos, os caminhos se tornavam cada vez mais longos. Primeiro, a melhoria da postura fez o homem caminhar ereto, tornando-o capazde ir mais longe. Então, ele encontrou a água-oque nãoé nenhuma surpresa, pois ela cobre cerca de $2 / 3$ de nosso planeta - e percebeu que ali podia se locomover melhor.

A princípio, a navegação se fez nos rios, de forma empírica. A orientação era dada por referências que se podiam avistar nas margens. O passo seguinte foi a navegação marítima, primeiramente costeira e, depois, oceânica.

Eis, aqui, um grande salto. $\mathrm{Na}$ navegação costeira, ainda é possível a orientação através de pontos avistados em terra. Para facilitar a orientação na navegação, algumas "pedras" iam sendo colocadas, como os faróis (o famoso Farol de Alexandria, por exemplo, é de 299 a.C.). Mas, em alto mar, não era possível ver pedra, tronco, árvore... nem mesmo montanha! Foi então que o homem olhou para cima, para o céu, e viu ali outras pedras: os astros!

Há vários registros de povos que, na antigüidade, tinham bom conhecimento de astronomia, o que lhes permitiam razoável orientação pelos astros. Nessa época alguns povos se aventuraram pelos oceanos e produziram cartas e livros de navegação. Então, foi que surgiram os primeiros instrumentos para a navegação astronômica, como o precursor do astrolábio, construído pelo astrônomo grego Hiparco (século II a.C.).

No início da Idade Média, a navegação estacionou ou mesmo regrediu. $\mathrm{O}$ isolamento dos feudos, auto-suficientes, desestimulou as grandes viagens. As poucas viagens empreendidas por alguns povos bárbaros eram feitas de maneira aindaempírica.

A esse tempojá seconhecia uma excelente referência, uma verdadeira "pedra azul", para os povos europeus: a estrela Polar, uma das estrelas da constelação da Ursa Menor, que é uma estrela fixa sobre o Pólo Norte. Mas essa "pedra” tem lá seus problemas: não pode ser vista durante o dia, nem nas noites nubladas e nebulosas. Além disso, ela também não poderia ser avistada do hemisfério Sul, no dia em que os navegadores cruzassem o Equador.

Uma outra "pedra azul" sempre esteve disponível, 24 horas por dia, sob qualquer condição meteorológica, em quase toda a superfície da Terra, mas faltava um instrumento que pudesse enxergá-la: o magnetismo do Pólo Norte. Esse instrumento, a bússola, deprovável origem chinesa, iria chegarà Europa somente por volta do ano 1000, tornando-se extremamente popular entre os navegadores a partir do século XIII. Na bússola, uma agulha imantada, flutuando numa tigela com água, aponta sempre para o norte da Terra.

A bússola, os portulanos (roteiros descritivos de viagens) e as cartas náuticas (primitivos mapas) acabaram dando novo impulso à navegação. Talvez pela sua peculiar posição geográfica, coube a Portugal o papel de centro de estudos e de avanços tecnológicos. A Escolade Sagres, criada pelo infante dom Henrique no início do século XV, reuniu cientistas e navegadores de toda a Europa, dando grande impulso à exploração portuguesa do Oceano Atlântico.

\section{Determinação das Coordenadas Geográficas}

A bússola, tal qual o uso da estrela Polar na Antigüidade, fornecia a direção a ser seguida, mas não era capaz de dar a posição da nau. No final da Idade Média, a determinação da posição de um ponto na superfície terrestre ainda era um grande desafio à ciência. Para se chegar a determinar a posição, era necessário que se definisse um sistemade coordenadas e um ponto de origem. Com o aprofundamento do conhecimento da geometria terrestre, foram criados os conceitos de latitude e longitude.

A determinação da latitude não foi grande problema. Desde a Antigüidade, sabia-se que astros, como a estrela Polar, são capazes de fornecer a direção ser seguida. Os portugueses, em Sagres, perceberam que, mais do que isso, a altura de certos astros, isto é, o ângulo sob o qual o astro é observado no céu, relativo à linha do horizonte, tem relação com a latitude do ponto de observação. No caso da estrela Polar, esse ângulo é a própria latitude do ponto de onde essa estrela é observada. Ao suldo Equador, de onde não é possível avistar a estrela Polar, poderia ser medida a altura do Sol ao meio dia, e a latitude seria fornecida por uma tabela previamente elaborada.

Para a medição desse ângulo, isto é, da altura de certas estrelas, foram desenvolvidos alguns instrumentos, dentre os quais o astrolábio, mais adequado para medir a altura do Sol, e o quadrante, precursor do sextante, que é usado até hoje. 
Assim, apesar de algumas restrições, como os problemas de nuvens e neblina e do balanço da nau (que prejudica a medição), a latitude já podia ser determinada, com razoável precisão.

A determinação da longitude, porém, permanecia insolúvel. Procurouse a ajuda dos astros, mas todas as soluções propostas foram ineficazes. Apesar de todas as tentativas, durante alguns séculos, a melhor maneira de se obter a longitude era por estima, isto é, baseava-se nas referências e descrições das cartas e, principalmente, na experiência do navegador.Era, portanto, um método altamente impreciso.

Jáse sabia que a horada observação de um fenômeno celeste-como o nascer do Sol, por exemplo - depende diretamente do lugar de onde é observado. Por comparação entre esse instante e a hora do meridiano de referência (o de Greenwich), e conhecendo-se a atitude, seria possível obter-se a longitude. Durante mais de dois séculos tentou-se resolver esse problema, até que, em meados do século XVIII, conseguiu-se construir um cronômetro suficientemente preciso para tanto.

Deste ponto, até hoje, tudo o que o homem tem feito é aprimorar cada vez mais os mecanismos de determinação da posição. As "pedras azuis" que vêm sendo colocadas, cada vez mais engenhosas e sofisticadas, têm tornado a navegação cada vez mais fácil e precisa.

\section{Avanços da Tecnologia}

Como em muitos ramos da ciência, um grande impulso foi dado à navegação durante a Segunda Guerra Mundial, quando a eletrônica, definitivamente, passou a servir como base para a instrumentação. Surgiram, nessa época, dois importantes sistemas, conhecidos pelos nomes de Loran (de "long range navigation" ou navegação de longo alcance) e Decca (Logsdon, 1992). Ambos se baseiamem ondas de rádio de alta frequiência emitidas por estações fixas, e captadas pelo veículo em movimento. Neste, um receptor é capaz de detectar o intervalo de tempo decorrido entre a emissão do sinal de rádio e sua recepção, podendo, assim, determinar a distância entre emissor e receptor. Conseguindo determinar as distâncias a três estações emissoras distintas, e sabendo suas respectivas posições através do método da triangulação, o receptor pode determinar a sua própria posição.

Embora sejam utilizados até hoje, esses sistemas apresentam algumas limitações. Em primeiro lugar, o alcance de uma estação emissoraé, em geral, restrito a algumas centenas de quilômetros. No caso da navegação marítima, por exemplo, essa restrição não prejudica navegação costeira, mas impede o uso desses sistemas para navegação em alto mar.

O sistema Omega (Logsdon, 1992), ao contrário dos sistemas Loran e Decca, utiliza ondas de baixa freqüência que apresentammaior alcance. Assim, com apenas oito estações fixas, localizadas na Noruega, Libéria, Havaí, Dakota do Norte (Estados Unidos), ilha de Diego Garcia (Oceano Índico), Argentina, Austrália e Japão, sua abrangência é mundial. Entretanto, da mesma forma que seus redecessores, seu uso acaba sendo limitado, prejudicado por interferências elétricas, condições atmosféacaba sendo limitado próficas. Com isso, certas aplicações, onde se faça necessária maior precisão no posicionamento, não são satisfeitas por instrumentos que utilizam os sistemas Loran, Decca e Omega.

Em fins da década de 50, a tecnologia deu mais um importante passo, ao se capacitar para colocar "pedras azuis" fabricadas pelo homem, onde antes só havia pedras naturais: o espaço. Dez anos após o início da Era Espacial (com o lançamento do satélite soviético Sputnik I, em 1957), entrava em operação o "Navy Navigation Satellite System", mais conhecido por Transit (Logsdon,1992). O princípio de seu funcionamento baseava-se no chamado "efeito Doppler", pelo qual a frequiência de um sinal emitido por uma fonte em deslocamento é alterada. Até recentemente muito usado pela navegação marítima especialmente pela transoceânica), ainda assim o sistema Transit apresentava algumas limitações: o pequeno número de satélites e a sua baixa órbita impediam que se pudesse obter a posição do receptor a qualquer momento; por se basear no efeito Doppler, apresentava elevada imprecisão quando o receptor se movimentava.

Finalmente, em 1973,nascia um novosistema de navegação e posicionamento, resultado indireto de todo esse conhecimento tecnológico, acumulado aolongo de muitos anos: o"Navigation Satellite with Time and Ranging/Global Positioning System" (Hurn, 1989). Mais conhecido como NAVSTAR/GPS ou, simplesmente, Sistema de Posicionamento Global (GPS), esse sistema foi concebido com fundos do Departamentode Defesa dos Estados Unidos para fornecer a posição instantânea ea velocidade de um ponto sobre a superfície terrestre ou próximo a ela. Inicialmente para fins militares, o GPS é hoje utilizado por diversos segmentos da sociedade civil, e seu uso tende a se popularizar cada vez mais.

Até hoje, o GPS é a mais sofisticada, engenhosa e eficiente ferramenta que o homem criou para saber sua posição na Terra. Desde 1973, estima-se que o governo norte-americano tenha investido mais de 12 bilhões de dólares no projeto. Nesse período, algumas alterações de ordem técnica foram introduzidas, e os constantes aprimoramentos da tecnologia têm provocado progressivo aumento na precisão. Hoje, já é possível obter-se uma precisão da ordem de centímetros para a posição de um determinado ponto.

\section{Sistema de Posicionamento Global}

\section{TrêsSegmentos}

O sistema GPS, como um todo, é composto por três segmentos: o segmento espacial,composto por satélites artificiais da Terra que emitem sinais eletromagnéticos; o segmento de controle, composto pelas estações terrestres que mantêm os satélites em funcionamento; e o segmento dos usuários, composto pelos receptores, que captam os sinais enviados pelos satélites e, com eles, calculam sua posição. 


\section{Segmento Espacial}

Numa primeira etapa do projeto do sistema, foram construídos 11 protótipos de satélites pela empresa Rockwell International. Esses satélites constituíram o chamado bloco I. Mais tarde, entraram em operação os satélites do bloco II, para o qual foram construídos 28 satélites, dos quais 24 foram lançados; e 21 satélites estão normalmente em operação e 3 ficam de reserva. A vida útil prevista para cada satélite é de 7 anos e meio. Hoje, estão sendo projetados e construídos, pela empresa General Electric, satélites de um terceiro bloco, denominado bloco IIR. Os satélites desse bloco já estão sendo lançados, em substituição aos do bloco anterior, introduzindo melhorias decorrentes dos avanços da tecnologia. E, para o início do róximo milênio, já se projetam os satélites do bloco IIF.

Cada satélite é dotado de painéis solares retráteis, que se constituem em sua fonte de energia. Quando estendidos, esses painéis conferem ao satélite um comprimento de aproximadamente $5 \mathrm{~m}$. Sua massa, em órbita, éde aproximadamente $1.000 \mathrm{~kg}$.

A órbita de um satélite é percorrida em, aproximadamente, 12 horas, o que significa que ele executa 2 voltas em torno da Terra a cada dia (na verdade, a órbita é completadaem 11 horase 58 minutos e,com isso, ele aparece nohorizonte 4 minutos mais cedo a cada dia). Os 24 satélites estão distribuídos em 6 órbitas distintas o que faz com que qualquer ponto da superfície terrestre tenha, próximo a ele, pelo menos 4 satélites acima da linha do horizonte. O plano de cada órbita forma, com o plano do Equador terrestre, um ângulo de $55^{\circ}$. A altura em que cada satélite executa sua órbita, em relação à da Terra, é de, aproximadamente, $20.000 \mathrm{~km}$.

Como se nota, ao contrário dos satélites comumente utilizados para comunicações, os satélites GPS não são geoestacionários, isto é, não permanecem numa posição fixa em relação à Terra acompanhando a sua rotação. Entre os motivos para esse fato, pode-se citar que, para ser geoestacionário, um satélite tem que permanecer no plano equatorial; se todos eles se situassem nesse plano, os pontos mais próximos aos pólos teriam uma cobertura menos favorável. Mas o principal motivo para se querer ter os satélites em rotação em torno da Terra é o de passar periodicamente próximo a uma estação de controle, podendo, assim, enviar e receber informações sobre sua órbita.

Em cada satélite há 2 relógios de césio e 2 de rubídio, altamente precisos, calibrados na freqüência de $10,23 \mathrm{MHz}$. Na verdade, a freqüência de ajuste é de $10,22999999545 \mathrm{MHz}$; a pequena diferença é para corrigir os efeitos relativísticos que fazem os relógios se adiantarem cerca de $38 \mu \mathrm{s}$

\section{Segmento de Controle}

Este segmentoé constituído por estações distribuídas ao longo da superfície terrestre, com a função de monitorar os satélites, efetuando eventuais correções em suas órbitas e em seus relógios. Há cinco dessas estações distribuídas pela superfície terrestre: a de Colorado Springs, no oeste dos Estados Unidos; a do

Havaí, Estados Unidos, no Oceano Pacífico; a de Kwajalein, nas ilhas norteamericanas das Carolinas, também no Oceano Pacífico; a da ilha de Ascensão, possessão britânic d 'lh d D' G $\mathrm{b}$ britânica, no Oceano Indico. A estação de Colorado Springs abriga o centro de operações do sistema, 
sinal pelo satélite e a sua efetiva recepção. Esse é o tempo de percurso do sinal, ou seja, o tempo necessário para o sinal percorrer a distância entre satélite e receptor Multiplicando esse tempo pela velocidade de deslocamento do sinal, o receptor obtém a sua distância ao satélite.

\section{Fontes de Imprecisāo}

A precisão na determinação da posição de um receptor depende da precisão das posições dos satélites e das distâncias a eles. O erro na determinação da posição de um satélite pode ocorrer em unção de um eventual desvio de órbita e do atraso com que esse desvio é detectado pelas estações de controle e registrado nas efemérides dos satélites. Esse erro, porém, é, em geral, bem pequeno (tipicamente, pode provocar imprecisão de $2,5 \mathrm{~m}$ na determinação da posição do receptor).

Já a medição da distância entre satélite e receptor pode ser afetada por uma série de fatores. Já foi visto que os desvios no relógio do receptor são filtrados por redundância, utilizando-se as informações fornecidas por um quarto satélite. No entanto, eventuais desvios nos relógios dos satélites não podem ser detectados pelo receptor. Também, aqui, o efeito na posição do receptor é pequeno (tipicamente de $1,5 \mathrm{~m}$ ), pois os relógios dos satélites são altamente precisos, e também monitorados pelas estações de controle.

Outro fator que influi na precisão das medidas é a variação da velocidade dos sinais eletromagnéticos emitidos pelos satélites, quando atravessam a atmosfera terrestre. A velocidade dos sinais, constante apenas no vácuo, é afetada por partículas ionizadas existentes na ionosfera) e pelo vapor d'água (existente na troposfera). É possível se fazer um modelamento da atmosfera que procura avalia os desvios da velocidade dos sinais dos satélites, mas esse modelamento nunca é perfeito, pois as condições atmosféricas se alteram de modo imprevisível Também, aqui, os efeitos no cálculo da posição do receptor não são muito elevados (tipicamente de 5,5m)

Há, ainda, os pequenos efeitos (da ordem de $0,6 \mathrm{~m}$ ) causados pelo fenômeno do "multicaminhamento", isto é, das múltiplas reflexões que o sinal de um satélite pode sofrer, em obstáculos próximos à antena do receptor. Tal fenômeno é semelhante ao "fantasma" que aparece na imagem de receptores de TV com antena.

Todos esses fatores, e ainda eventuais imprecisões do receptor GPS somados conduzem a um erro típico, na determinação da posição do receptor, da ordem de dezena de metros.

Ocorre, porém, que há ainda um outro fator responsável pela elevação do erro a cerca de $100 \mathrm{~m}$ : a chamada "disponibilidade seletiva". O Departamento de Defesa dos Estados Unidos, operador dos segmentos espacial e de controle, pode, a qualquer momento, introduzir erros propositadamente que afetam tanto a determinação da posição dos satélites (alterando as efemérides) quanto o cálculo da distância dos satélites aos receptores (alterando os relógios dos satélites). Apenas alguns receptores do exército americano e de seus aliados não são afetados por esseserros. Concebido inicialmente para serutilizado em épocas de guerra, o recurso da disponibilidade seletiva tem sido mantido ligado quase que ininterruptamente desde que foi introduzido, apesar dos protestos do segmento civil dos usuários.

\section{Mecanismos de Correção}

A técnica chamada de "GPS diferencial" veio amainar os protestos dos usuários contra o acionamento da disponibilidade seletiva Com essa técnica consegue-se obter uma precisão total entre $2 \mathrm{~m}$ e $5 \mathrm{~m}$, mesmo com a disponibilidade seletiva ativada. Seu princípio é bastante simples: além do receptor GPS itinerante, isto é, que e locomove pelos pontos cujas coordenadas se deseja determinar, utiliza-se um outro receptor GPS, chamado de base ou de referência, que permanece fixo num ponto cuja posição é bem conhecida. Esse receptor de referência, utilizando os sinais que recebe dos satélites, determina a sua posição, sujeita a todos os erros anteriormente descritos. Comparando-a com a sua posição real, previamente conhecida, ele pode, a cada instante, determinar o erro a que está sujeito o sinal enviado por cada satélite que ele avista. Dessa forma, o receptor de referência pode corrigir os erros dos sinais captados pelo receptor itinerante, assumindo que esses erros sejam os mesmos.

É evidente que isso não se pode garantir. As imprecisões introduzidas pelo próprio receptor, por exemplo, são específicas para cada aparelho: o receptor de referência não pode avaliar os erros provocados pelas características do receptor itinerante. Os efeitos do multicaminhamento são particulares a cada receptor e não podem ser corrigidos. Já os efeitos da atmosfera podem ser bastante atenuados, quanto mais próximos os receptores itinerante e de referência se mantiverem.

Finalmente, os erros introduzidos por desvios na órbita e no relógio interno dos satélitespodem ser totalmente eliminadospela técnica do GPS diferencial. Notese que, nesta categoria de erros, enquadram-se os produzidos pela ativação da disponibilidade seletiva.

Uma outra técnica, já bem mais complicada, é utilizada em aplicações que exigem maior precisão, da ordem de milímetros, como levantamentos topográficos medições geodésicas. Essa técnica se baseia no princípio da interferometria, e pode exigir umacomplexa rede de estações de base. Os cálculos envolvidos sãobastante complexos e as medições efetuadas exigem cuidados especiais - a perda de uma particular medida pode comprometer toda a operação de determinação de uma posição.

\section{Aplicações}

Embora tenha sido concebido há mais de vinte anos, o sistema GPS só recentemen

os 24 satélites prevıstos. E, mesmo assim, certamente o sistema está bem longe 
de sua configuração definitiva: conforme já foi apresentado, um novo bloco de satélites está sendo projetado e construído, com algumas melhorias em relação ao atual. Ainda se discute que outras melhorias poderão vir a ser implementadas.

Outro fator que pode impulsionar o aperfeiçoamentodo sistema GPS é a sua descaracterização como instrumento militar. Na época de sua concepção, em meio à "Guerra Fria", com o mundo dividido em dois blocos claramente antagônicos, o grande apelo para se conseguirem recursos financeiros necessários ao projeto era o seu potencial bélico. Vinte anos depois, o mundo mudou, as perspectivas são outras... e, felizmente, o uso do GPS para fins pacíficos parece ser bem mais abrangente. Chega a ser curioso que á existam, no mercado, receptores capazes de processar; simultaneamente, sinais enviados tanto pelos satélites GPS norteamericanos) quanto pelos satélites GLONASS (sistemarusso, semelhante ao GPS).

Tal qual vem ocorrendo com a indústria da informática, o que se observa é que a cada dia surgem novos fabricantes de instrumentos, lançando novos produtos, cada vez mais precisos e sofisticados, ao mesmo tempo em que o aumento da demanda colabora na redução dos preços. No início dos anos 80 , o modelo mais barato de um receptor GPS não custava menos do que 140 mil dólares. Dez anos depois, esse valor játinha caído para 2 mil dólares. Hoje, uma loja qualquer de artigos eletrônicos em Miami, é possível encontrar um receptor por 200 dólares.

Fica, pois, difícil estimar-se, hoje, o número de modelos diferentes de receptores GPS existentes no mercado, bem como o número de unidades em operação. É bem possível que o cálculo de 200 modelos e de 2 milhões de unidades já esteja totalmente superado.

Numa tentativa de se agruparem as suas diversas aplicações, citam-se aqui três "categorias", embora formalmente essa classificação não exista. Essas categorias são: geodésia, coleta de dados e navegação.

\section{Geodésia}

A categoria de aplicações de geodésia engloba as que exigem os receptores de maior precisão, da ordem de centímetros ou milímetros. As aplicações desse grupo envolvem topografia, altimetria, cartografia, geologia, sensoriamento remoto, agrimensura etc. Receptores GPS estão sendo utilizados, por exemplo, para a medição e o monitoramento do deslocamento das placas dacrostaterrestre. No Brasil, técnicos do Instituto Brasileiro de Geografiae Estatística (IBGE) empregam receptores GPS para o refinamento da rede de marcos geodésicos do país (Fortes et al., 1996).

\section{Coleta de Dados}

Os receptores que se classificam como "coletores de dados" não necessitam ter tanta precisãocomo os utilizados em geodésia. Precisões da ordem de $1 \mathrm{~m}$, e mesmo de 5m, são, em geral, satisfatórias para estas aplicações. Além de determinarem sua posição, eles permitem, por exemplo, que seu operador defina categorias e classificações para os elementos a serem coletados, criando uma espécie de "dicionário de dados". Quando sai a campo, o operador apenas seleciona as características do elemento a ser cadastrado. As aplicações, aqui, são muito variadas: planejamento urbano, planejamento rural, planejamento de traçados de estradas e dutos, cadastramento de espécies animais e vegetais, mapeamento de tipos de solos, mapeamento de sistemas de transmissão e distribuição de energia elétrica etc.

\section{Navegação}

O terceiro grupo de aplicações, aqui chamado de aplicações de navegação, geralmente exige do receptor um comportamento dinâmico e uma resposta imediata. Emalguns casos, é necessária alta precisão, como na aplicação militar de navegação de mísseis e nos sistemas de aterrissagem de aeronaves. Mas, na maioria das aplicações, é satisfatória uma precisão na faixa entre $2 \mathrm{~m}$ e 100m (neste último caso, a técnica do GPS diferencial não é necessária). Receptores GPS já são largamente utilizados na navegação aérea e marítima. Um grande mercado que agora começa a ser bastante explorado é o da indústria automobilística. Alguns modelos de veículos japoneses já são oferecidos com receptores GPS, enquanto locadoras norte-americanas colocam à disposição de seus clientes veículos com computador de bordo acoplado a um receptor. O gerenciamento e monitoramento de frotas de caminhões e ônibus têm sidobastante aprimorado com a instalação de receptores nos veículos da frota. E até atividades esportivase de lazer, comoenduros, excursões e caminhadas ecológicas, já empregam receptores GPS.

\section{Aplicaçōes de GPS em Turismo}

A seguir, são apresentados dez casos que exemplificam o uso do GPS em atividades ligadas ao Turismo. O primeirodeles demonstra o potencial do sistema como ferramenta de divulgação de atrativos turísticos e de orientação aos turistas mostrando a importância que lhe deve ser dada pelas autoridades responsáveis pelo Turismo de uma região (Mertikas et al., 1997). Os sete casos seguintes enquadramse no chamado "Turismo de Aventuras", modalidade que vem ganhando, a cada dia, maior número de adeptos (Fernandes, 1997; Elias, 1997; Kubota e Faoro, 1997). Finalmente, os dois últimos casos enfatizam o uso do GPS na navegação de veículos (Krakiwsky, 1996).

\section{Na llha de Creta: achando a saida do labirinto}

Por centenas de anos, a ilha de Creta, perdida no meio do Mediterrâneo, permaneceu desconhecida e ignorada por quase toda a população mundial. Até que, 
em 1900, o arqueólogo britânico, Sir Arthur Evans iniciou escavações em Cnossos que acabaram ajudandoa reconstituir a história de uma civilização dourada.

Hoje, mais de 1 milhão de turistas visitam anualmente a ilha, onde outrora o rei Minos construiu o famoso Labirinto, em cujo centro habitava o legendário Minotauro, um estranho ser, metade homem, metade touro.

E, muito em breve, esses turistas poderão estar utilizando um dispositivo portátil, multimídia, dotado de um receptor GPS, que os ajudará a se guiarem pelas intrincadas ruas de Creta, da mesma forma que ofiode um novelo de lã ajudou Teseu a achar a saída do Labirinto.

Esse dispositivo, denominado "Minotauros", está sendo desenvolvido pelo "MUSIC-Multimedia Systems Institute of Crete" (Instituto de Sistemas Multimídia de Creta). Baseia-se na integração de GPS, GIS ("Geographic Information System" /Sistema de Informações Geográficas), bases dedados, sistemas multimídia e redes de computadores. Seu objetivo é fornecer ao turista informações geográficas, históricas, climáticas, sociológicas, dentre outras, substituindo, dessa forma, as fontes tradicionais de informação.

Em vez de consultar pesados livros e guias, mapas complicadose uma enorme quantidade de brochuras e prospectos, o turista tem acesso às informações que lhe interessam através de um único dispositivo, podendo se inteirar sobre a história, a geografia e os pontos turísticos de uma área escolhida, bem como sobre os eventos culturais e esportivos durante um certo período desejado. E graças ao GPS, o turista é orientado em suas viagens pelas estradas da ilha, que são apresentadas em um mapa digital na telade um computador, no qual é também mostrada a posição de seu veículo.

O sistema Minotauros é composto pelo centro operacional, fonte das informações e pelas unidades portáteis, que são conduzidas pelos turistas. Em cada unidade, um microcomputador apresenta, em sua tela, um mapa da ilha, no qual os pontos de interesse turístico, como monumentos, museus ou montanhas, bem como cidades e vilas, estão assinalados por pequenos círculos. Para fazer uma "visita" virtual a um ponto, o turista o seleciona, com o uso do "mouse". Informações nas mais diversas formas (fotos, textos, pequenas seqüências de filmes e de som) são apresentadas pelo computador. Nesse mesmo mapa, a posição exata do turista é mostrada através de um ponto piscante. As principais atrações das proximidades de onde o turista se encontra também são destacadas no mapa. Assim que o turista chega a uma delas, lhe são fornecidos dados mais detalhados a respeito, na forma de texto ou de informações sonoras.

Em 1996, um protótipo do sistema foi testado na área de Chania, na porção ocidental da ilha. A cidade de Chania, sede da MUSIC, abriga a segunda maior população de Creta, com 60 mil habitantes (atrás apenas de Hêrakleion, no centro da ilha, com 120mil). Além de atrações históricas, como as ruínas da antigacidade de Kastelli, ficam em Chania o Museu Histórico de Creta e o mercado público, inspirado no mercado de Marselha, na França.

Nos seus arredores, há outros pontos muito procurados pelos visitantes: a cidade de Aptera, cujas origens remontam ao ano 700 a.C.; as ruínas do Castelo Selino, uma fortaleza construída em 1279; o estreito de Samaria que, com 18km, é o mais longo da Europa; e o lago Kournas, o único de toda a ilha. Por suas características, a área de Chania mostrou-se bastante adequada aos testes que foram realizados.

Nesses testes, a unidade portátil tinha três componentes: um computador portátil (modelo "laptop"), um receptor GPS e um modem.

O computador é o componente básico do sistema. Ele apresenta as informações ao turista, e dele recebe comandos. Possui, ainda, unidades de armazenamento de dados (como CD-ROMs), contendo informações multimídia.

$O$ receptor GPS capta os sinais emitidos pelos satélites da constelação GPS e calcula sua posição geográfica (latitude, longitude e altitude), fornecida ao microcomputador a cada segundo. $\mathrm{O}$ modem, finalmente, opera como um telefone celular, servindo de meio para a comunicação com o Centro de Operações. Dentre os dados transmitidos e recebidos, incluem-se notícias do dia, previsões do tempo, eventos culturais e esportivos, programação de excursões, reservas em hotéis etc.

O equipamento foi embarcado num veículo, para um "test drive". Inicialmente, foi visitada a área do velho porto Veneziano. Os venezianos ocuparam a cidade em 1252, e a chamavam "La Canae" (o canal), origem de seu nome. Ainda hoje restam trechos das muralhas construídas naquela época. Apesar das várias rebeliões empreendidas pelos cretenses, os venezianos dominaram a ilha até 1669 , quando o Império Otomano a conquistou.

Durante o percurso pelas estreitas ruas da área portuária - um verdadeiro "labirinto" por entre tavernas e cafeterias repletas de gente-, a posição do automóvcl foi sendoconstantemente atualizada pelo receptor GPS, enquanto o modem garantiu a troca de dados com o Centro de Operações. Conforme era esperado, a posição corrente do veículo foi sendo mostrada no mapa apresentado na tela do computador.

Para testar o fornecimento de dados "estáticos" (isto é, previamente gravados), foram solicitadasinformações sobre a igreja Agios Pavlos, em Agia Roumeli, onde se acredita que São Paulo batizava seus seguidores, a caminho de Roma. Localizada a $50 \mathrm{~km}$ de Chania, a pequena capela fica numa praia, e só pode ser alcançada pelo mar. Em poucos segundos, após uma consulta ao disco (CD-ROM), uma "janela" apareceu na parte esquerda da tela do computador, com informações gerais a respeito da igreja Agios Pavlos, ao mesmo tempo que, à direita, surgiu uma foto da capela. Outro teste semelhante, solicitandoinformações sobre o farol do porto Veneziano, resultou na apresentação de um pequeno vídeo sobre o porto e seus arredores.

Restava serem testados os dados "dinâmicos", isto é, os obtidos através da comunicação com o Centro de Operações. Antes disso, porém, o veículo foi conduzido até o velho monastério de Agia Triada, erguido em 1632. Em suas proximidades, fica o aeroporto de Chania, bem comoum outro monastério, ode Nossa Senhora dos Anjos, fundado em 1548, com uma igreja coberta por belas escultura venezianas. Durante todo o trajeto, o veículo foi corretamente rastreado e apresentado no mapa digital.

Nesse local, foi feita uma solicitação de informações dinâmicas: a programação dos cinemas de Chania. Isso deveria provocar a comunicação, via fone celular, 
entre a unidade móvel, instalada no automóvel, e o Centro de Operações, na sede do MUSIC. No entanto, foi constatado que interferências causadas pela topografia da região provocaram ruídos eletrônicos, que impediram o correto funcionamento do sistema.

$\mathrm{O}$ resultado insatisfatório do teste motivou uma alteração no projeto do equipamento. Incorporou-se ao equipamento ummóduloadicional de memória, para armazenar informações dinâmicas, carregadas uma só vez por dia, na ati vação do aparelho. Essa solução funcionou bem para as informações pouco dinâmicas, embora as informações em tempo real (como a reserva em hotéis) ainda exigissem comunicação direta, via telefone celular.

Utilizando o sistema Minotauros, foram "visitados" virtualmente vários pontos turísticos, num raio de $50 \mathrm{~km}$ em torno de Chania. Muitas dessas atrações foram efetivamente visitadas, com o auxílio do sistema de navegação, baseado no receptor GPS. Os testes mostraram a viabilidade e a funcionalidade do sistema.

No futuro, pretende-se incorporar melhorias, tais como a possibilidade da emissão de comandos verbais pelo turista, o suporte a diversas línguas e o refinamento do sistema de navegação, com o emprego da técnica do GPS diferencial. Está sendo estudada a possibilidade de se substituir o microcomputador "laptop" por um equipamento ainda menor e mais leve.

Com essas melhorias, tem-se a expectativa do sistemaser ainda mais acessível aos turistas que chegam a Creta todos os anos, intrigados pelo curioso passado da ilha e cativados pelo seu clima saudável. Em breve, graçasao sistema Minotauros, os turistas não terão mais que se preocupar com o intrincado sistema viário e suas ruas estreitas, podendo tranqüilamente passear pelas praças, igrejas e ruínas de palácios, ou simplesmente relaxar nas praias de areias brancas, iluminadas por um sol brilhante e banhadas pelas águas azuis-claros do mar Mediterrâneo.

\section{Nas Praias do Brasil: caminhando do Chuí ao Oiapoque}

Na bela canção Lígia, Tom Jobim exalta a delícia que é andar pela praia de Copacabana até a do Leblon. Para a maioria dos brasileiros, trata-se de uma bela, mas longa, caminhada. Mas para o geógrafo carioca Sérgio Rondelli, 41 anos, e o fotógrafo capixaba Canário Caliari, 33 anos, esse passeio é mais curto do que "ir até ali na esquina".

Afinal, os dois amigos saíram do Arroio Chuí, em 2 de fevereiro de 1996, e chegaram ao Oiapoque, na divisado Brasil com a Guiana Francesa, no dia 16 de abri de 1997, depois de passarem quatorze meses caminhando pelos $8.000 \mathrm{~km}$ do litoral brasileiro. Foram cerca de 2 mil praias visitadas, em dezessete Estados.

Essa não foi a primeira aventura da dupla. Em 1993, eles já haviam percorrido $300 \mathrm{~km}$ do litoral entre o Espírito Santo e Porto Seguro, na Bahia, em onze dias. E, no ano seguinte, fizeram os $411 \mathrm{~km}$ do litoral capixaba (ambos moram em Vitória, ES).

A expedição Chuí-Oiapoque foi coberta com os recursos obtidos por dois patrocinadores e custou cerca de $R \$ 120$ mil, incluindo máquinas fotográficas, câme fraças a esses equipamentos, foram tiradas $40 \mathrm{mil}$ fotos, das quais algumas serão selecionadas para uma exposição itinerante. Os aventureiros planejam editar um livro e um guia de "trekking", além de proferir palestras para empresários e estudantes.

Na verdade, além da aventura pura e simples de percorrer o litoral a pé, Sérgio e Canário tinham uma missão de natureza técnica: a de localizar e medir a extensão e Canário tina das praias visitadas. Utilizando um receptor GPS, eles descobriram diversos erros na localização e no tamanho de algumas praias nos mapas, embora toda a costa brasileira já tenha sido fotografada por satélites e mapeada por navegantes.

Outro resultado do trabalho da dupla, realizado para o "Guia Quatro Rodas de Praias", foi a avaliação das condições ambientais do litoral brasileiro. Como já era esperado, foi constatada a existência de enormes regiões devastadas pela poluição e pela especulação imobiliária. No entanto, algumas descobertas foram surpreendentes. Na costa há uma infinidade de paraísos quase intocados pelo ser humano. Os $300 \mathrm{~km}$ do litoral sul do Estado de São Paulo, por exemplo, exibem exuberante Mata Atlântica e praias limpas e bem preservadas.

Do total do percurso, $85 \%$ foi feito a pé. Em média, $18 \mathrm{~km}$ diários. Alguns trechos, especialmente nas regiões de mangue, tiveram que ser percorridos de barco ou de avião, como a etapa final entre Macapá e o Oiapoque, pois a costa do Amapá além de não terpraias, é inacessível por terra. Por outrolado, logo no início da viagem, os dois atravessaram os $212 \mathrm{~km}$ da praia do Cassino, no Rio Grande do Sul, a mais extensa do mundo, sob forte chuva de granizo.

No Atlântico e nos dois Pólos: acompanhando o navegador solitário

Ele se formou em Economia pela Universidade de São Paulo; fez cursos de complementação em Administraçãode Empresas e Literatura Francesa; e trabalhou em banco. Mas os grandes feitos de Amyr Klink, que o fizeram famoso no Brasil e no mundo, foram suas viagens, especialmente a travessia do Atlântico, a remo, e a navegação, em um veleiro, aos pólos sul e norte, devidamente documentadas nos belos livros Cem Dias entre o Céu e o Mar e Paratii - entre dois Pólos.

Alguém que não o conheça poderia considerá-lo um aventureiro desajuizado, um louco irresponsável. Completo engano! Na verdade, as viagens de Amyr, por ele chamadas de projetos, são cuidadosamente estudadas, planejadas, programadas. Como ele mesmo gosta de enfatizar, a etapa mais trabalhosa, a qual exige maiores esforços, é justamente a do planejamento.

Especialista em logística, Amyr Klink é um profundo conhecedor de cartografia e deequipamentos náuticos. Meticuloso e apaixonado, ele lêtoda a bibliografia disponível e se mantém atualizado, acompanhando todas as novidades da tecnologia.

Não é surpresa, portanto, que ele tenha sido um dos primeiros brasileiros a tomar conhecimento do GPS. Em 1939, ele o utilizou em sua viagem à Antártida, 
numa época em que os receptores mais baratos custavammais de US $\$ 5$ mil, e, mesmo assim, seu funcionamento era limitado pelos poucos satélites então em órbita. Apesar de poder ser utilizado apenas 2 horas por dia, o receptor acabou lhe sendo bastante útil, especialmente nas proximidades da Moff Island, uma ilha acima do paralelo $80^{\circ}$ Norte, no Ártico. Numa situação de extremo perigo, em que os métodos convencionais de navegação eram impraticáveis, foi o receptor GPS que lhe possibilitou adotar a estratégia correta para contornar a ilha.

Amyr não se limita a usar receptores GPS apenas em viagens de barco. Freqüentemente, ele pilota helicópteros e pequenas aeronaves, nas quais usa o GPS aeronáutico. Agora, seu objetivo é integrar GPS e cartas náuticas digitais, embora ainda haja muitos lugares ainda não mapeados digitalmente.

No momento, Amyr Klink está envolvido num novo projeto: uma viagem de volta ao mundo, por uma rota polar, chegando à China pelo Ártico, e não pelo caminho convencional. O barco, uma evolução do Parati, já está sendo construído, e deverá ser equipado com o que há de mais moderno em termos de tecnologia.

Certamente, ele terá um receptor GPS.

\section{No Veleiro na Costa Brasileira: navegando com uma familia}

Eles formavam um típico casal classe média. Vilfredo, economista e empresário. Heloísa, dona de casa. Um dia, tomaram uma decisão que mudou suas vidas: adquiriram um veleiro, pegaram os três filhos (Pierre, Wilheim e David) e lançaramse ao mar, deixando para trás a bonita Florianópolis, em Santa Catarina, onde moravam. Isso aconteceu em abril de 1984. Só voltaram ao Brasil dez anos depois.

Nesse período, o casal Schurmann viveu momentos de intensa emoção e aventura, relatados nolivro Dez anos nomar, escrito por Heloísa. Navegaram cerca de $150.000 \mathrm{~km}$, passando por toda a costa brasileira, pelo Caribe, pela Flórida, pelo Canal do Panamá, pelo Pacífico Sul e pela costa sul da África.

Motivação e disciplina foram, segundo eles, as principais razões para o sucesso da empreitada. A cada dia surgia uma surpresa ou um imprevisto, para os quais eles tinham que estar preparados. Foi um aprendizado constante, de diferentes culturas e hábitos.

Para serem bem recebidos pelos diversos povos que visitavam, era importante conhecerem seu ambiente e seus costumes - uma experiência que Vilfredo pretende, através de palestras, passar a empresas que buscam novos mercados.

Mas, porenquanto, a família está envolvida em um novo projeto: em outubro de 1997, eles partiram para uma viagem de circunavegação, refazendo a rota seguida pelo famoso navegador português Fernão de Magalhães que, em 1519, empreendeu a primeira volta ao mundo. O retorno promete ser apoteótico: a chegada está prevista para o dia 22 de abril de 2000, em Porto Seguro, local onde Pedro Álvares Cabral aportou, exatos 500 anos antes.
Nessa viagem, os Schurmann pretendem empregar toda a tecnologia disponível atualmente: computadores, Internet, vídeos, cartas náuticas digitais e, evidentemente, um receptor GPS, equipamento que conheceram em 1992, na Nova Zelândia temente, um receptor GPS, equipamento considerado "um incrível aparelho de navegação por satélite com capacidade de precisar o ponto onde o barco está". Assim, será ossível a qualquer pessoa acompanhá-los, via Internet, recebendo suas coordenadas em tempo real, e imagens "ao vivo".

\section{No Topo do Mundo: cada vez mais alto}

Ele passou por maus momentos em 1989, porocasiãode sua primeira escalada ao Aconcágua (6.960m), na Argentina, o ponto culminante da América do Sul. Sem conseguir se localizar, impossibilitado de usar um altímetro, em virtude das tempestades de vento e neve, ele passou 24 horas perdido no deserto de Atacama, só se salvando quando pôde traçar sua rota, orientando-se pelas estrelas.

Desde então, o alpinistabrasileiro Waldemar Niclevicz, autor do livro Everest - Diáriode uma Vitória, já fez várias outras escaladas,incluindoo Everest $(8.848 \mathrm{~m})$ ponto culminante da Ásia (e do mundo); o Elbruz (5.633m), na Rússia; o Vinson (4.898m), mais alto pico da Antártida; e o Kilimandjaro (5.895m), ponto fulminante da África. Mais recentemente, em maio de 1997, ele tingiu o topo do McKinley (6.194m), no Alasca, o mais alto da América do Norte. E, em setembro de 1997, ao conquistaro Cartensz Pyramid(4.884m), na Oceania, ele se tornou o primeiro brasileiro a juntar-se ao seleto grupo de 28 alpinistas que venceram o desafio conhecido por "Sete Cumes do Mundo", que consiste em alcançar os principais picos dos continentes.

A fim de evitar situações desagradáveis e perigosas como as que passou em 1989, Waldemar tem procurado se utilizar dos mais modernos instrumentos de navegação, dentre os quais o receptor GPS.

Segundo ele, o GPS foi fundamental no Alasca, especialmente nos trechos de glaciares, verdadeiros rios de gelo, que chegam a atingir $3 \mathrm{~km}$ de largura. Os glaciares provocam o fenômeno conhecido como "white-out", pois atraem densas camadas de nuvens, que impedem totalmente a visibilidade. Mesmo sem poder enxergar um palmoà sua frente, o alpinista podia manter a sua rota, graças ao receptor GPS.

Ao contrário de um navegador, que pode ter em seu barco um sistema completo de navegação, incluindo o computador de bordo, às vezes grande e pesado, o alpinista tem que contar com equipamentos compactos, leves e resistentes, pois leva tudo em sua mochila. Por isso, Waldemar procura aproveitar os avanços tecnológicos, desde que atendam aos critérios de preço e, especialmente, de praticidade.

Ele não tem dúvidas de que o receptor GPS atende a esses requisitos. 


\section{Nos Andes: iluminando o caminho dos alpinistas}

O “Ojos del Salado", na cidade de Resistência, na Argentina, é o segundo mais alto pico dos Andes, com mais de 6.900m de altura. Em janeiro de 1997, ele foi escalado por quatro amigos da cidade de Curitiba, Paraná, dentre os quais odentista Marcos Iwamura.

Na subida, munidos apenas com um mapa "xerocado", eles passaram por momentos difíceis, como uma tempestade de neve, o que os atrasou, fazendo com que só atingissem o cume da montanha ao anoitecer. Isso aumentou o perigo da descida. Qualquer erro na rota poderia ser fatal.

Para evitar riscos, o grupo decidiu pegar uma valeta, a $6.000 \mathrm{~m}$ de altura, por onde poderiam deslizar. Encontrar a valeta, porém, só foi possível graças à rota traçada através do receptor GPS. Sem esse instrumento, o tempo que seria perdido poderia impedir um retorno seguro.

Marcos lembra, ainda, outra utilidade do receptor. Durante a descida, feita no escuro, as lanternas do grupo ficaram com as ilhas descarregadas. Com as mãos endurecidas e dormentes pelo frio intenso, eles contaram com a ajuda da luz do visor do instrumento ara trocar as baterias.

Na próxima aventura, Marcos e seus amigos pretendem ir mais bem equipados: rádio VHF, bússola, "walkie-talkie", mapas originais... e, no mínimo, dois receptores GPS.

\section{Nas estradas do Brasil: tomando conta das meninas}

Há quem duvide que elas consigam vencer o desafio. Mas, em maio de 1997, asestudantes paulistanas Mariana Pimenta(20anos), Flávia Renault(21)e Alessandra Peixoto (23) partiram, decididas, em sua viagem de $50.000 \mathrm{~km}$ pelo Brasil, a bordo de um automóvel da marca Subaru.

Antes de saírem pelas estradas, elas passaram quatorze meses planejando a viagem, estudando as dificuldades e determinando a rota. Fizeram cursos de mecânica e de primeiros socorros, e conversaram com outros aventureiros mais experientes.

Em dezembro de 1996, saíram de São Paulo rumoà Bahia, percorrendo um caminho através da Mata Atlântica. De lá, seguiram para o Agreste pernambucano, interior do Ceará e Maranhão, ingressando nas precárias estradas da Amazônia. Elas pretendiam passar pelo monte Roraima e, depois, iniciar a descida ao sul, passando pelo Acre, Pantanal mato-grossense, Foz do Iguaçu e Uruguaiana, ja na divisa com o Uruguai. Na volta a São Paulo, ainda estavam previstas visitas ao Parque Nacional dos Aparados da Serra, na divisa de Santa Catarina com o Rio Grande do Sul, e Vila Velha, no Paraná.

Além do planejamento meticuloso, elas contam com a tecnologia a bordo de seu veículo, especialmente projetado para a viagem. Graças a um receptor GPS e a um rádio transmissor, elas estão sendo rastreadas 24 horas por dia, pela agência central da Autotrac, empresa especializada no rastreamento de veículos, com sede em Brasília e que tem o tricampeão mundial de Fórmula I, Nélson Piquet, como principal sócio.

Através desse sistema, as meninas podem, ainda, enviar mensagens que são repassadas a Helena Costa, responsável pelo seu monitoramento, na base em São Paulo. O mais importante, para elas, é a questão da segurança. Em qualquer ponto do país, a qualquer momento do dia ou da noite, elas podem acionar um botão de pânico, caso ocorra algum problema. Imediatamente elas são localizadas na central em Brasília.

\section{Nos Quatro Cantos das Américas: nas asas de} um monomotor

Gérard Moss é inglês e sua esposa, Margi, queniana. Ambos são radicados no Rio de Janeiro e têm uma paixão em comum: a aviação.

Em 1989, eles realizaram um feito notável: uma viagem de volta ao mundo, a bordo de umpequeno aviãomonomotor, descrita em um livro. No meio da expedição fizeram uma descoberta que mudou radicalmente o seu plano de viagem: um receptor GPS. Graças a ele, eles puderam atravessar o Pacífico, da Austrália para o Chile, fazendo uma única escala para reabastecimento na ilha de Páscoa, a ilha mais isolada do mundo, e célebre pelas figuras esculpidas na pedra, de autoria ainda misteriosa. Sem o GPS, essa rota seria muito arriscada, pois qualquer desvio poderia provocar a falta de combustível $\mathrm{e}$ a conscqüente queda no mar. Convencidos da utilidade do aparelho, eles nunca mais deixaram de utilizá-lo em seus vôos.

A bordo de um avião modelo Sertanejo, contando com dois receptores (um fixo no painel e outro portátil), o casal partiu do Rio de Janeiro, em janeiro de 1997, para mais um desafio. Desta vez, o objetivo era atingir os quatro extremos do continente americano.

Eles passaram pelo extremo sul, no Chile, e pelo extremo oeste, no Alasca. Sobrevoaram regiões belíssimas, como o recortado litoral chileno; os misteriosos e gigantescos desenhos de Nazca, no Peru; os muitos vulcões da América Central e a paisagem branca das geleiras do Alasca, produzindo horas e horas de filmes que estão sendo exibidos na TV, além de boletins veiculados ao vivo por emissoras de rádio. Depois, eles rumaram para o norte do Canadá, de onde seguiram à Ponta Seixas, no Cabo Branco, em João Pessoa, no Estado brasileiro da Paraíba, extremo Oriente das Américas. Comodizem os orgulhosos paraibanos, ali eles puderam visitar o local onde, no Brasil, "o sol nasce primeiro".

\section{Nos Parques da Disney: tomando conta da criançada}

A cidade de Orlando, na Flórida, nos Estados Unidos, tem um excepcional apelo turístico. Em seus arredores se localizam importantes parques temáticos como o Reino Mágico da Disneyworld, o Epcot Center, os estúdios da Universa 
e da MGM, o Sea World, atraindo, anualmente, milhões de visitantes.

Por causa disso, a região oferece ampla infra-estrutura de serviços, desde hotéis e restaurantes às transportadores e locadoras de automóveis. Uma das maiores empresas deste último ramo, a locadora Avis, já há alguns anos tem oferecido um produto diferenciado a seus clientes em Orlando e em outras cidades norteamericanas. Em maio de 1996, mais de mil veículos para locaçãojá tinham computadores de bordo. Sua concorrente, a Hertz, prometia, para outubro, um produto semelhante em 8 mil veículos.

Em cada automóvel, uma antena capta os sinais transmitidos pelos satélites GPS e,com eles, o computador calcula sua posição. Na tela do computador, um mapa mostra a localização exata do veículo e dos principais pontos de interesse, como atrações turísticas, hotéis, restaurantes ou bancos. O motorista ode indicar o seu destino desejado, e o equipamento o guiará, apontando o melhor percurso. Para não desviar a atenção do motorista, alguns aparelhos são capazes de receber comandosde voz, e de emitirem respostassonoras. Comodiz Terry Gordon, relações públicas da Avis, é possível uma viagem entre dois pontos quaisquer dos Estados Unidos, sem a necessidade de se consultar um único mapa impresso em papel.

Esses sistemas de navegação para veículos já são uma realidade. A fábrica alemã BMW já os oferececomoopcional, em seus modelos ais sofisticados, o mesmo acontecendo com diversas fábricas japonesas. Mas a criatividade e as aplicações do GPS não param nessa particularidade. Também em Orlando, mais especificamente nos parques da Disney, já se pensa em sistemas de navegação para crianças e adolescentes! A idéia é simples. Ao entrar no parque, cada criança receberia uma espécie de pulseira, dotada de um receptor GPS e de um rádio transmissor, ambos miniaturizados. $\mathrm{O}$ receptorGPS detecta a posição, que é transmitida pelo rádiopara uma estação central. Pulseira semelhante foi testada em prisioneiros em regime semi-aberto que,impedidos de deixar sua cidade, são monitorados pelas autoridades policiais. No caso da Disney, cada criança poderia ser rastreada por seus pais ou responsáveis, a cada instante, em qualquer canto do parque!

\section{Nos Meios de Transporte: conduzindo viajantes com totalsegurança}

O setor dos transportesé um dos maisimportantes da indústria do Turismo, e um dos que mais tem se beneficiado doGPS. Por serum sistema de posicionamento, o GPS é bastante utilizado na navegação de veículos. Deve-se salientar que a aplicação original do sistema era, justamente, a navegação de mísseis militares.

Atualmente, presume-se que a maior quantidade de receptores existentes seja utilizada na navegação de embarcações de todos os portes: dos grandes transatlânticos aos pequenos veleiros, para um único tripulante. Nesse segmento não há grande necessidade de precisão, especialmente se a embarcação está em alto mar os $100 \mathrm{~m}$ garantidos pelos equipamentos mais simples são mais do que suficientes nesses casos. Não é por acaso que os receptores mais baratos podem, em geral, se encontrados em lojas de artigos náuticos e para pesca.

A perspectiva, no entanto, é que, no futuro, os veículos terrestres, especialmente os automóveis de passeio, sejam os grandes usuários do sistema. Além de servir como instrumento de navegação, um verdadeiro "guia eletrônico", o receptor GPS tem sido, também, utilizado como um dispositivo de segurança, pois permite que o automóvel seja rastreado por uma estação central de monitoração.

$\mathrm{O}$ aspecto da segurança é, também, o principal apelo para a instalação de receptores GPS em caminhões. No Brasil, tem sido muito comum o roubo de cargas especialmente nas estradas mais distantes dos grandes centros. Com o rastreamento dos veículos, fica um pouco mais fácil a recuperação das cargas, o que seria quase dos veículos, fica um pouco mais

O gerenciamento de frotas de veículos terrestres é outra aplicação do GPS que vem ganhando força ultimamente. Em algumas grandescidades do mundo, como o Rio de Janeiro, as viaturas policiais são rastreadas pela Central de Despachos que pode enviar ao local de uma ocorrência a viatura disponível nais próxima. Pelos mesmos motivos, os veículos de bombeiros eambulânciastambém têm se beneficiado do sistema. Em ambos os casos, pode ainda haveruma interligação entre o sistema de rastreamento dos veículos e o sistema de atuação em semáforos, facilitando o deslocamento das viaturas nas cidades sujeitas a um ráfego pesado.

O transporte ferroviário, metroviário e de frotas de ônibus também têm suas razões para o uso do rastreamento feito através de receptores GPS. Em função da disposição espacial dos veículos e da demanda de passageiros, um determinado veículo pode ser propositadamente acelerado ou retardado, a fim de otimizar o espaçamento dentro de uma mesma linha.

A grande discussão sobre o uso do GPS em transportes, porém, é no setor aéreo. Nesse caso, a exigência é precisão. OGPS jáé competitivo com outros sistemas tradicionais de navegação de aeronaves, a não ser nas operações de pouso e decolagem, justamente as mais delicadas. No entanto, já se projetam alterações no sistema, para que o GPS seja homologado como o principal sistema de navegação de grandes aviões, substituindo, com vantagens, os caros e volumosos instrumentos utilizados atualmente.

\section{Considerações Finais}

Este artigo procurou mostrar como os campos de aplicação do Sistema de Posicionamento Global (GPS) são bastante amplos e variados. Graças ao avanço tecnológico, o sistema tem se aperfeiçoado cada vez mais, aumentando a precisão na determinação das posições, ao mesmo tempo em que se reduzem os custos dos equipamentos.

Evidentemente, o Turismo é um dos setores que mais vantagens poderá conseguir com o aperfeiçoamento do sistema. Como foi demonstrado, o uso de receptores GPS em aplicações turísticas já é bem expressivo, e a tendência é que venha a crescer cada vez mais no futuro. Provavelmente, em pouco tempo, esse instrumento 
será bastante popular, tornando-se um acessório obrigatório para qualquer viajante. É de suma importância para o profissional que atua em Turismo, o conhecimento sobre o GPS e o potencial de suas aplicações.

\section{Referências Bibliográficas}

ELIAS, J. 1997. GPS guia aventureiros no mar, ar e terra. Jornal da Tarde, São Paulo, 20 mar. p.8D-10D. FERNANDES, M. 1997. Do Chuí ao Oiapoque. Veja, São Paulo, ano 30, n.16, p.94-5.

FORTES, L.P.S.; OLIVEIRA, L.C.; FERREIRA, L.F. 1996. Ensaio decomunicação de dados para a RBMC. Anais do GIS Brasil 96. Curitiba, p.426-36.

HURN, J. 1989. GPS. A guide to the next utility. Estados Unidos: Trimble Navigation, Sunnyvale.

KUBOTA, M.; FAORO, L. 1997. Um lugar no mundo com o GPS. Fator GIS, Paraná, n.19, p.48-52.

KRAKIWSKY, E.J. 1996. Driving ITS development: technology and maket forces. GPS World, Estados Unidos, v.7, n.10, p.50-5.

LOGSDON, T. 1992. The NAVSTAR Global Positioning System . Nova Iorque: Van Nostrand Reinhold.

MERTIKAS, S.; CHRISTODOULAKIS, S.; KONTOGIANNIS, 1997. P. Island of miracles: exploring Crete's treasures with Minotauros. GPS World, Estados Unidos, v.8, n.5, p.22-30.

PAZ, S.M. 1997. Uma ferramenta para desenvolvimento de equipamentos que utilizem um receptor do Sistema de Posicionamento Global (GPS). São Paulo: EDUSP, 1997. Dissertação (Mestrado). 